(new photometrical methods in light metal analysis); Dr. Ramb (various spectro-analysis investigations for industrial laboratories) and Dr. Kaiser (contributions to the spectro-analysis of light metal alloys). The third day's work was on fine measuring, the lecturers being Prof. Kienzle (means of obtaining reliable dimensional data regarding machine com. ponents); Dipl.-Ing. Claassen (supervision of gear wheel manufacture); Dr. Berndt (testing of gear teeth) and Herr Nichterlein (modern developments in projection as a means of measuring).

\section{Engineering and Transport}

IN his presidential address to the Institute of Transport on October 11, Sir Alexander Gibb suggested that we are on the threshold of another great advance in methods of transport. He did not speak of the experiments that the great physicists of the world are carrying out in their laboratories; he confined himself to consideration of the most that engineers can offer, to improve transport with the knowledge and means they have at present. In constructing bridges, the record for length $(4,200$ feet) is held by the Golden Gate Bridge at San Francisco. He said that American engineers are confidently looking forward to building, within the next ten years, spans up to 10,000 feet long. With present materials and the development of wire cable construction, it is quite possible to expand this length to 18,000 feet; but before this limit is reached, the ratio of dead load to live load would be too great to make spans of this length economically justifiable. In air transport the speeds at which aeroplanes will regularly operate will before many years equal or exceed the highest speed records at the present time, and the distances over which they will operate will be greatly extended. Sir Alexander doubts, therefore, whether floating seadrome bases or mother seaplane ships will over be necessary for great ocean crossings.

At the moment, road design is the most urgent of the problems of transport engineering. It is purely a matter of policy and economics whether Great Britain should endeavour to develop road systems like those in Germany. In Great Britain there are 41,000 miles of road subject to the 30 m.p.h. restriction; and more than half the Great North Road is only suitable for two-line traffic, although we have the greatest density of motor traffic on the roads of any country in the world. Germany recently in one year spent 25 million pounds on entirely new road construction, and in 1935 the United States spent about 120 million pounds. In Great Britain the building of a new road is a rare event. A complete programme of new trunk motor roads in Great Britain, connecting all the principal towns, might cost up to a thousand million pounds. A further attempt to solve the traffic problems of London in the way that New York is dealing with its difficulties, on the lines of the regional plan of 1929, with its forty years programme, involving about 1,700 miles of parkways, boulevards, etc., would cost more. It might even not be possible. Sir Alexander pointed out that these are not exclusively engineering problems. They must be examined from the economic point of view before a decision can be reached.

\section{The Hanseatic Scholarships}

IT is announced in The Times that a Hamburg merchant, who desires to remain anonymous, has created out of his private means a fund to provide in the first instance not fewer than four scholarships annually, each of the value of 3,000 Rm., for young British graduates who desire to study in Germany. These scholarships are to be known as the Hanseatic Scholarships. They will be tenable for one year, may be held in any subject, and will be open to all students of the universities of the British Empire, with a preference for students from Great Britain. The founder hopes that the Hanseatic Scholarships may help "to further closer relations and understanding between the German and British peoples and to promote a consciousness of European solidarity". The trust, of which the first patron is the German Ambassador at the Court of St. James's, will be assisted in the selection and guidance of the scholars by a German and a British committee. The British committee, as so far constituted, will consist of : Lord Lothian (chairman), Dr. W. G. S. Adams, Prof. E. D. Adrian, Dr. George Gordon, Sir Henry Tizard, and Prof. H. G. Fiedler (secretary), professor of German language and literature, University of Oxford, from whom further particulars may be obtained.

\section{Association of British Chemical Manufacturers}

TwENTY-ONE years of activity were reviewed by the chairman, Mr. Eben Wallace, at the annual general meeting, held on October 14, of the Association of British Chemical Manufacturers, which was formally incorporated on December 28, 1916. The initial membership was 110 firms, representing a capital of $£ 39,000,000$, whereas now, although the actual membership has not shown any great increase,

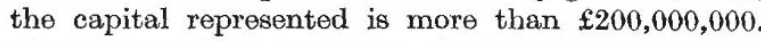
The Association's directory, "British Chemicals and their Manufacturers", was first published in 1919, and a new edition has since been issued every second year. $1920 \mathrm{saw}$ the formation of the British Chemical Plant Manufacturers' Association, whilst in 1927 the Association's Works Technical Committee commenced its work on safety in the chemical industries. Other activities have been concerned with fiscal matters, with the setting up of standards, with the organization of exhibitions, with the incidence of legislation, and, generally, with the promotion of co-operation within and around the industry. The annual report refers to the Association's activities, during the year ended May 31 last, in relation to the new Factories Act and other legislation, to the work of the Import Duties Advisory Committee, to commercial treaties, to safety measures, to the fund which the chemical industry has established in support of chemical publications and library facilities, to trans. port, and to various other relevant matters. Dr. F. H. Carr was elected president of the Association, and Mr. E. V. Evans and Mr. R. Duncalfe respectively chairman and vice-chairman of the council. 